\title{
Female Labor Force Participation Rate in Indonesia: An Empirical Evidence from Panel Data Approach
}

\author{
Gatot SASONGKO \\ Bernard Edheney HURUTA2 \\ Andrian Dolfriandra HURUTA3*
}

\begin{abstract}
Economic development constantly faces various macroeconomic issues such as achieving inflation targets, creating job opportunities, increasing economic growth, solving unemployment problems, and flattening income distribution. This study aims at analyzing the impact of provincial minimum wages, economic growth, and education level on female labor force participation rate. We generated the data from Indonesia's Central Bureau of Statistics website. This study employs panel data that consists of the time-series data from 2014 to 2018 and cross-sectional data of 34 provinces in Indonesia. By using the fixed-effect econometric model, we demonstrate that the provincial minimum wage and education level have significantly positive effects on female labor force participation rate. However, economic growth has no significant effect on female labor force participation rate. These findings suggest that the Indonesian government needs to consider minimum wages, education, work age, and work experience as policy instruments to increase female labor force participation rate. This study contributes to the literature in Indonesia by using a panel data approach.
\end{abstract}

KEYWORDS: female labor force participation rate, provincial minimum wage, economic growth, education level, panel data

JEL CLASSIFICATION: E24, E29

\section{INTRODUCTION}

The Indonesian Central Bureau of Statistics (2019) reports that there were differences between male and female labor force participation rates. In February 2019, the male labor force participation rate was $83.18 \%$, while the female labor force participation rate was only $55.50 \%$. Compared to 2018 , the female labor force participation rate increased by $0.06 \%$ while the male labor force participation rate decreased by $0.17 \%$. The national labor force participation rate exhibited a positive trend, as indicated by an annual increase of 0.12 from February 2018 was $69.20 \%$ to $69.32 \%$ in February 2019. The increase in the Indonesian labor force participation rate indicates an increase in economic potentials in terms of labor supply. Todaro and Smith (2015) argue that the agricultural sector is traditionally considered to play an only passive and supporting role because this sector mainly provides labor and cheap food supplies sufficiently for the emerging industrial economies. However, most development

\footnotetext{
1 Faculty of Economics and Business, Satya Wacana Christian University, Indonesia, gatot.sasongko @ staff.uksw.edu

2 Faculty of Economics and Business, Satya Wacana Christian University, Indonesia, 222014019 @ student.uksw.edu

3 Faculty of Economics and Business, Satya Wacana Christian University, Indonesia, andrian.huruta @ staff.uksw.edu, *Corresponding author
} 
economists today hold a common consensus that the agricultural sector no longer only plays a passive role and should play an essential role in any development strategy, especially for lowincome emerging countries. Since the last 20 years, Southeast Asia countries have experienced increased productivity amid the rapid structural transformations, as indicated by increased productivity in the agriculture, manufacturing, and services sectors. It is then understandable that a large number of the population in this region is dominated by those who look for work (including the female population). The World Bank (2014) and IndonesiaInvestments (2019) report that the number of unemployed young females is higher than the unemployment of young males in Indonesia. However, female unemployment has decreased faster than male unemployment. Thus, the gender inequality factor likely plays an important role in the Indonesian government's decisions. Although many women have contributed to education and health, they still tend to work in the informal sector (twice as many as the number of men in the sector). Further, most women work for lower wages and are paid less than males for similar works.

Several studies have analyzed the determinants of female labor force participation rate. For example, they focus on the contribution of women in the agricultural sector (Er, 2013), the decision to become the breadwinner and commit in marriage (Varol, 2017), residential ownership (Kizilgöl, 2012), the value of weekly opportunity cost, work experience, husband's main job, and work culture (Chodijah, 2008), the number of female residents who are still in school and take care of households (Setyowati, 2009), age (Riyadi, 2001; Varol, 2017; Kizilgöl, 2012; Varol 2017; Chodijah, 2008), fertility (Çatalbaş, 2015; Lee \& Chung, 2008), social status (Riyadi, 2001; Chodijah, 2008), divorce rate (Çatalbaş, 2015), family factors particularly caring for children (Chen, Shao, Murtaza \& Zhao, 2014; Varol, 2017; Chodijah, 2008), and inflation (Niemi \& Lloyd, 1981; Özer \& Biçerli, 2003; Chen, Shao, Murtaza \& Zhao, 2014).

Further, several scholars have already analyzed the different factors that affect the female labor force participation rate. For example, wages (Johnson, 2014; Hare, 2016; Sarsi, Putro, \& Sari, 2014; Özer and Biçerli, 2003), education level (Er, 2013; Hare, 2016; Handayani and Majid, 2012; Riyadi, 2001; Varol, 2017; Kizilgöl, 2012; Bozkaya, 2013; Çatalbaş 2015; Chodijah, 2008), economic growth (Mujahid \& Zafar, 2012; Lechman \& Okonowicz, 2013; Tsani, Paroussos, Fragiadakis, Charalambidis, \& Capros, 2013; Jaba, Sandu, Plopeanu, Robu \& Istrate, 2017; Tam, 2011; Özer \& Biçerli, 2003; Lahoti \& Swaminathan, 2013).

Previous studies on female labor force participation rate demonstrate inconclusive results. Furthermore, these studies use different methods and variables related to female labor force participation rate in various countries. This study revisits the initial findings and contributes to the literature of female labor force participation rate by using a panel data approach since Indonesia is an archipelago country with thousands of islands. As such, this study is essential to analyze the effect of provincial minimum wages, education level, and economic growth on the provincial female labor force participation rate in Indonesia.

This study is motivated by the need to identify female labor force participation rate in Indonesia because of the gaps between males and females workforce in Indonesia. We use the panel data analysis such as stationary panel test, ordinary least squares, fixed-effect, and random-effect. The time-series period starts from 2014 to 2018, while the cross-sectional data covers 34 provinces in Indonesia. This study is arranged in several sections. The second section discusses the literature review. The research methods are described in the third section. In the fourth section, we present the empirical findings. The fifth section follows by discussing the findings. Lastly, the sixth section concludes and presents limitations and suggestions for future research. 


\section{LITERATURE REVIEW AND HYPOTHESIS DEVELOPMENT}

\subsection{Labor force participation rate}

Ehrenberg and Smith (2012) define labor force participation rate as a percentage of the workforce relative to the working-age population. Labor force participation rate indicates the percentage of the working-age population who are economically active in a region. Several factors affect labor force participation rate, including the number of schooling population, the number of the population who take care of households, age, wage level, and education level. In this study, labor force participation rate refers to female labor force participation rate that is measured by comparing the female workforce with the number of the female working-age population. More specifically, the number of female workforce from each province will be weighted by the number of the female population aged 15 years and over.

\subsection{Minimum wage}

Minimum wage affects labor force participation rates. Increased minimum wage will reduce labor demand, while wage is a compensation for labors for their contributions to productive activities. Increased minimum wage motivates labor force to work (Mankiw, 2016). In this study, minimum wage refers to provincial minimum wage as legally stipulated by the Indonesian Minister of Manpower and Transmigration Regulation No. 7 of 2013 concerning minimum wages. Studies on the effect of minimum wages on female labor force participation rate demonstrate inconsistent results. For example, Johnson (2014) and Hare (2016) document the positive effect of minimum wages on female labor force participation rate. However, Sarsi, Putro, and Sari (2014) show that minimum wage negatively affects labor force participation rate. Meanwhile, Özer and Biçerli (2003) demonstrate that minimum wage does not affect female labor force participation rate. Based on these findings, we propose the following hypothesis:

$\boldsymbol{H}_{1}$ : Provincial minimum wage has a significant effect on female labor force participation rate.

\subsection{Education level}

The number of graduates indicates the availability of an educated population in a region. Hence, higher education levels will likely increase labor force participation rate. Samuelson and Nordhaus (2009) propose that the wage level of each workforce is always different due to different labor quality. The differences in labor quality itself are affected by mental traits, physical abilities, the number of graduates (including training), and experience with the most instrumental factors are the number of graduates and experience. Because individuals have different abilities, those with higher abilities likely contribute more to the productive activities and receive higher income as a reward to their contributions. In this study, the average length of schooling is the proxy of education level. Studies on the effect of education level on female labor force participation rate demonstrate inconclusive results. For example, Er (2013), Hare (2016), Handayani and Majid (2012), Riyadi (2001), Varol (2017), Kizilgöl (2012), Bozkaya (2013), and Çatalbaş (2015) observe the positive influence of education levels on female labor force participation rate. Meanwhile, Chen, Shao, Murtaza, and Zhao (2014) find that education level has a negative effect on female labor force participation rate. Lastly, Chodijah (2008) documents that education level does not affect female labor force participation rate. Based on these findings, the following is the second hypothesis:

$\mathrm{H}_{2}:$ Education level has a significant effect on female labor force participation rate. 


\subsection{Economic growth}

Gross national product (GNP) or gross domestic product (GDP) and gross regional domestic product (GRDP) measures aggregate economic growth (Mankiw, 2016). In this study, we measure economic growth by using the components of the gross regional domestic product of each province in Indonesia. Studies on the effect of economic growth on female labor force participation rate demonstrate inconsistent results. For example, Mujahid and Zafar (2012), Lechman and Okonowicz (2013), Tsani, Paroussos, Fragiadakis, Charalambidis, and Capros (2013), Jaba, Sandu, Plopeanu, Robu and Istrate (2017) find the positive effect of economic growth on female labor force participation. However, Tam (2011) and Lechman and Okonowicz (2013) show that economic growth negatively affects female labor force participation rate. Meanwhile, Özer and Biçerli (2003) and Lahoti and Swaminathan (2013) demonstrate that economic growth does not affect female labor force participation rate. Based on these findings, the following hypothesis was proposed:

$\boldsymbol{H}_{3}$ : Economic growth has a significant effect on female labor force participation rate.

\section{RESEARCH METHODOLOGY}

This study uses data from the Indonesian Central Bureau of Statistics publication (2014 to 2018). The secondary data reveals that the panel data that consists of two parts, namely timeseries and cross-section data. The time-series data are annual data for five years. Meanwhile, the cross-section data covers thirty-four provinces in Indonesia. The panel combines crosssection data and time-series data (Gujarati \& Porter, 2012). In terms of panel data, we detect data stationarity by using a unit root test that will be observed with the method of Levin, Lin, and Chu (Granger \& Newbold, 1974).

$Y_{i t}=\rho_{i} Y_{i t-1}+X_{i t} \delta_{i}+u_{i t}$

where $Y_{\text {it }}$ represents pooled variable, $X_{\text {it }}$ represents exogenous variables in the model, including fixed effects or individual trends, $\rho_{\mathrm{i}}$ is an autoregressive coefficient, and error $\varepsilon_{\mathrm{it}}$ is assumed to be a separate idiosyncratic disturbance. Whereas the following is the commoneffect model proposed in this study:

$\operatorname{DLFPR}_{\text {it }}=\beta_{0}+\beta_{1}$ DWage $_{\text {it }}+\beta_{2}$ DEduc $_{i t}+\beta_{3}$ DGrowth $_{\text {it }}+$ Uit $_{\text {it }}$

where,

$\begin{array}{ll}\text { DLFPR }_{\text {it }} & : \begin{array}{l}\text { Female labor force participation rate of the i province in year } \mathrm{t} \text { at first } \\ \text { difference order }\end{array} \\ \text { DWage }_{i t} & : \begin{array}{l}\text { The provincial minimum wage of the i province in year } \mathrm{t} \text { at first difference } \\ \text { order }\end{array} \\ \text { DEduc }_{\mathrm{it}} & : \text { Education level rate of the i province in year } \mathrm{t} \text { at first difference order } \\ \text { DGrowth }_{\mathrm{it}} & : \text { Economic growth in the i province of year } \mathrm{t} \text { at first difference order } \\ \beta_{0} & : \text { Constant } \\ \beta_{1,} \beta_{2,} \beta_{3} & : \text { Coefficients of regression } \\ \epsilon_{\mathrm{it}} & : \text { Eror term in the i province in year } \mathrm{t}\end{array}$

Other models that can be applied in panel data regression are the fixed effect model (3) and the random effect model (4) (Winarno, 2015). 
DLFPR $_{i t}=\beta_{1}$ DWage $_{i t}+\beta_{2}$ DEduc $_{i t}+\beta_{3}$ DGrowth $_{i t}+\alpha_{i}+u_{i t}$

DLFPR $_{i t}=\alpha+\beta_{1}$ DWage $_{i t}+\beta_{2}$ DEduc $_{i t}+\beta_{3}$ DGrowth $_{i t}+\lambda_{i}+u_{i t}$

In a panel data regression, the random-effect model uses the generalized least square method while the fixed-effect model and common-effect model use the ordinary least square (Gujarati \& Porter, 2012).

\section{FINDINGS}

In this section, we provide several statistical test results. Table 1 displays the results of the Levin, Lin, and Chu's unit root test.

Table 1. Unit root test

\begin{tabular}{|c|c|c|c|}
\hline Variables & $\begin{array}{c}\text { Degree } \\
\text { of Integration }\end{array}$ & p-value* & Conclusion \\
\hline DLFPR & $\mathrm{I}(1)$ & $0.0000^{* *}$ & Panel is stationary \\
\hline DWage & $\mathrm{I}(1)$ & $0.0000^{* *}$ & Panel is stationary \\
\hline DGrowth & $\mathrm{I}(1)$ & $0.0000^{* *}$ & Panel is stationary \\
\hline DEduc & $\mathrm{I}(1)$ & $0.0000^{* *}$ & Panel is stationary \\
\hline
\end{tabular}

Notes:

DLFPR indicates female labor force participation rate at the first-order difference

DWage indicates provincial minimum wage at the first-order difference

DGrowth indicates economic growth at the first-order difference

DEduc indicates education level rate at the first-order difference

(*) Levin, Lin \& Chu

(**) Significant at a significant level of $1 \%, 5 \%$, and $10 \%$

Source: secondary data, processed.

Table 1 indicates that female labor force participation rate has been stationary at the firstorder difference ( $p$-value < the critical value of 0.05 ). Similarly, the other variables, such as provincial minimum wage, economic growth, and education level, have also been stationary at the first-order difference.

This study uses the ordinary least squares, fixed effect, and random effect because several scholars have indicated that these models are appropriate for our research objectives. The panel ordinary least squares is an effective model because it minimizes squared residuals and increases the accuracy of the test. Similarly, the fixed effect is an appropriate model to control for the province effect. Whereas, the random effect produces more similar outcomes when we have time-variant and time-invariant variables.

Table 2. The panel estimations of OLS, fixed-effect, and random-effect

\begin{tabular}{|c|c|c|c|c|c|c|c|c|c|}
\hline \multirow{2}{*}{ Variables } & \multicolumn{4}{|c|}{ OLS Regression } & \multicolumn{3}{c|}{ Fixed-Effect Model } & \multicolumn{3}{c|}{ Random-Effect Model } \\
\cline { 2 - 10 } & Coef. & t-stat. & Prob. & Coef. & t-stat. & Prob. & Coef. & t-stat. & Prob. \\
\hline \multirow{2}{*}{ DWage } & $-4.11 \mathrm{E}-$ & - & & & & & & & \\
& 06 & 1.052888 & 0.2943 & $6.79 \mathrm{E}-06$ & 6.692684 & $0.0000^{*}$ & $7.51 \mathrm{E}-07$ & 0.125627 & 0.9002 \\
\hline DGrowth & 0.070345 & 0.431003 & 0.6672 & 0.015819 & 0.370273 & 0.7120 & 0.057567 & 0.333344 & 0.7394 \\
\hline DEduc & 7.669807 & 1.219973 & 0.2246 & 9.010197 & 3.253943 & $0.0016^{*}$ & 13.16768 & 1.595674 & 0.1130 \\
\hline $\mathrm{R}^{2}$ & 0.011974 & - & - & 0.439833 & - & - & 0.022386 & - & - \\
\hline DW stat & 2.256688 & - & - & 2.644995 & - & - & 2.252658 & - & - \\
\hline
\end{tabular}

Note: $(*)$ represents the statistical significance level of $1 \%, 5 \%$, and $10 \%$, respectively.

Source: secondary data, processed. 
Table 2 presents the results of the fixed-effect and random-effect estimation of the panel OLS. We only explain the results of estimations that are more appropriately reported by using the fixed effect. We present a method to estimate and predict fixed effects in a panel model when $\mathrm{N}$ is large and $\mathrm{T}$ is small (Gujarati \& Porter, 2012). The results of the fixed effect model show that the coefficient values of provincial minimum wage and education level are significantly positive, implying that these variables positively affect female labor force participation rate. Also, the $\mathrm{R}^{2}$ value is $43.98 \%$. The $\mathrm{R}^{2}$ value is generally lower in cross-sectional analysis than in time-series models. The $\mathrm{R}^{2}$ value is not too high in a panel data analysis because of the heterogeneity of cross-sections. If the panel data is more time-dominant, $\mathrm{R}^{2}$ will be arguably higher than when the panel data is more dominantly cross-section (PeiZhi \& Ramzan, 2020). In the fixed-effect model, it is essential to focus on the constant differences between objects, as illustrated by Table 3 below.

Table 3. The cross-section effect

\begin{tabular}{|l|c|l|c|}
\hline \multicolumn{1}{|c|}{ Province } & Effect & \multicolumn{1}{c|}{ Province } & Effect \\
\hline Aceh & -0.447000 & West Nusa Tenggara & 1.035995 \\
\hline North Sumatra & 0.634692 & East Nusa Tenggara & 0.222775 \\
\hline West Sumatra & 0.534314 & West Kalimantan & 0.146974 \\
\hline Bangka Belitung & -1.155314 & South Kalimantan & -10.35619 \\
\hline Riau Islands & 0.752975 & Cental Kalimantan & -0.285765 \\
\hline Riau & 0.007625 & East Kalimantan & 1.014211 \\
\hline Jambi & 0.154441 & North Kalimantan & 0.578412 \\
\hline Bengkulu & 0.256653 & Gorontalo & -0.438542 \\
\hline South Sumatra & 0.047424 & North Sulawesi & 1.001024 \\
\hline Lampung & 1.172972 & Central Sulawesi & -0.702860 \\
\hline Banten & 1.192278 & Southeast Sulawesi & -0.843480 \\
\hline Jakarta & 0.506324 & South Sulawesi & -0.117179 \\
\hline West Java & 0.556535 & West Sulawesi & -0.627755 \\
\hline Central Java & 0.829852 & Maluku & 0.094102 \\
\hline Yogyakarta & 3.103418 & North Maluku & 0.809876 \\
\hline East Java & 1.124307 & Papua & -1.031177 \\
\hline Bali & 0.177077 & West Papua & 0.051002 \\
\hline
\end{tabular}

Source: secondary data, processed.

Table 3 shows that about $29.41 \%$ of Indonesia's 34 provinces have negative constant values. Thus, female labor force participation rate will decrease by its constant value while the independent variable is zero. Conversely, $70.59 \%$ of Indonesia's 34 provinces have positive constant values, suggesting that female labor force participation rate will continue to increase by the constant value when the independent variable is zero.

\section{DISCUSSION}

The results of the fixed-effect model support hypothesis 1 that predicts that provincial minimum wage has a significantly positive effect on female labor force participation rate (Johnson, 2014; Hare, 2016). In Indonesia, the findings can be explained through the monopolistic labor market. Firms in monopsonistic labor markets have to make two hiring decisions. First, like firms in competitive labor markets, they need to determine the number of labor they hire. This decision is consistent with the profit-maximizing criterion by calculating the amount of employment at $\mathrm{MRP}_{\mathrm{L}}=\mathrm{ME}_{\mathrm{L}}$. Second, the firm must consider the wage rate required to hire $\mathrm{E}^{*}$ workers. In this case, the rate of pay attracts $\mathrm{E}^{*}$ workers is $\mathrm{W}^{*}$ (note $\mathrm{Y}$ on the labor supply curve). The firms' labor supply curve reflects the relationship between their future 
wage levels and the number of workers attracted to work in these firms. Thus, graphically, the second decision (e.g., wages) refers to the wage required to attract the profit-maximizing number of employees from the labor supply curve. Figure 1 below illustrates the decision.

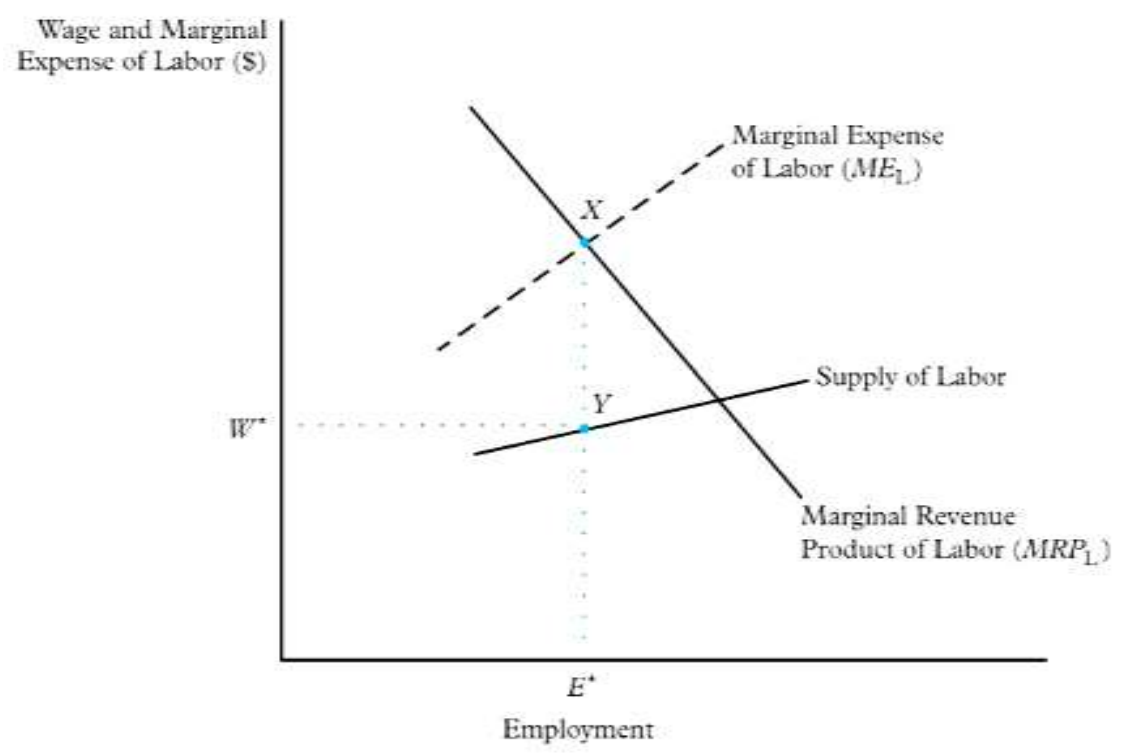

Figure 1. Profit-Maximizing Employment and Wage Levels of Firms Facing Monopsonistic Labor Markets

Source: Ehrenberg and Smith (2012)

In the monopsonistic labor markets, minimum wages will increase average costs and reduce marginal spending. Hence, marginal costs will also be lower to encourage firms to increase outputs. Also, firms will pay higher wages to improve the product quality made by their workers. In other words, higher wages will be attractive to prospective workers because they arguably indicate better job opportunities, particularly for women.

The fixed-effect model also supports hypothesis 2 that predicts that education level positively affects female labor force participation rate (Er, 2013; Hare, 2016; Handayani \& Majid, 2012; Riyadi, 2001; Varol, 2017; Kizilgöl, 2012; Bozkaya, 2013; Çatalbaş, 2015). In Indonesia, female workers who enter the labor market are those who belong to certain education levels. Table 4 below demonstrates the results.

Table 4. The impact of female workforces' education levels on economic growth (2014 to 2018)

\begin{tabular}{|c|c|c|c|c|}
\hline Variable & Coefficient & Std. Error & t-Statistic & Prob. \\
\hline No Schooling & -1.556743 & 0.973157 & -1.599683 & 0.3557 \\
\hline $\begin{array}{c}\text { Not Yet Completed Primary } \\
\text { School }\end{array}$ & -1.745410 & 1.607650 & -1.085690 & 0.4739 \\
\hline Primary School & 7.666874 & 4.854520 & 1.579327 & 0.3593 \\
\hline Junior High School & -5.873665 & 0.318850 & -18.42140 & $0.0345^{*}$ \\
\hline General Senior High School & -8.397181 & 1.030208 & -8.150955 & $0.0777^{* *}$ \\
\hline Vocational Senior High School & 5.689910 & 0.304537 & 18.68381 & $0.0340^{*}$ \\
\hline Vocational Tertiary Degree & 3.964738 & 3.435285 & 1.154122 & 0.3677 \\
\hline University Degree & -1.229389 & 1.956617 & -0.628324 & 0.5940 \\
\hline
\end{tabular}

Note: $(*),(* *)$ denote significance at the level of $5 \%$ and $10 \%$, respectively

Source: secondary data, processed. 
Table 4 shows that the absorption of female workforce increases employment opportunities for those who have education levels that match and link better with available employment opportunities such as vocational senior high school and tertiary degree. The findings indicate the increased need for specialized skills and competencies (Alamro \& Al-dala'ien, 2016; Dimian et al., 2018). Hence, increased economic growth is likely followed by increased employment opportunities for women in certain education levels such as junior high school, general senior high school, and vocational senior high school. In Indonesia, the absorption of female workforce is evident only in certain education levels, thus illustrating that better link and match between education and employment increase female workforce.

Further, the fixed-effect model does not support hypothesis 3 that predicts that economic growth affects female labor force participation rate (Özer \& Biçerli, 2003; Lahoti \& Swaminathan, 2013). In Indonesia, the female workforce participation rate only increases in certain age groups, as illustrated in Table 5 below.

Table 5. The impact of female workforces' age groups on economic growth (2014 to 2018)

\begin{tabular}{|c|c|c|c|c|}
\hline Variable & Coefficient & Std. Error & t-Statistic & Prob. \\
\hline $15-19$ & -0.06 & 0.0524 & -1.14 & 0.459 \\
\hline $20-24$ & 3.523 & 1.8833 & 1.87 & 0.313 \\
\hline $25-29$ & -7.092 & 2.9157 & -2.43 & 0.248 \\
\hline $30-34$ & 16.98 & 1.0671 & 15.91 & $0.04^{*}$ \\
\hline $35-39$ & 67.325 & 3.9926 & 16.86 & $0.038^{*}$ \\
\hline $40-44$ & -42.7 & 2.5837 & -16.53 & $0.038^{*}$ \\
\hline $45-49$ & 11.228 & 6.4866 & 1.73 & 0.334 \\
\hline $50-54$ & -11.15 & 5.3065 & -2.1 & 0.283 \\
\hline $55-59$ & 3.422 & 4.2583 & 0.8 & 0.569 \\
\hline $60+$ & 0.5142 & 0.5834 & 0.88 & 0.443 \\
\hline
\end{tabular}

Note: (*) Significant at the level of $5 \%$.

Source: secondary data, processed.

Table 5 indicates that the absorption of female workforce is much more evident in certain age groups. More specifically, the results show that the 35-39 years old group has the highest coefficient of 67.325 percent, thus implying that increased female workforce in this age group is not followed by an increase in the overall (national) female workforce. This condition illustrates that increased economic growth does not increase national female workforces.

\section{CONCLUSIONS}

Female labor force participation rate is an important issue in Indonesia. The Indonesian population is dominated by those who look for works (including women). Also, the gap between men and women still exists in the Indonesian labor market. However, the male labor force participation rate was relatively stagnant in current years, while the female labor force participation rate revealed a significant increase. The figures suggest that women contributed increasingly to the Indonesian economy. Using the fixed-effect model, we document that provincial minimum wage and education levels have significantly positive effects on female labor force participation rate. However, economic growth has no significant effect on the female labor force participation rate. In other words, our empirical findings support hypotheses 1 and 2 but not hypothesis 3 . 
In the Indonesian case, the monopolistic labor market causes female labor force participation rate to increase. Also, the link and match between education and employment facilitates female labor force participation rate to increase. However, the absorption of female labor forces by specific age groups explains the fact that economic growth does not affect female labor force participation rate.

From the policy perspective, the Indonesian central and provincial governments need to maintain minimum wages to motivate and help women earn decent wages and increase female workers' competence through education that enhances human resource quality (human investment). Furthermore, arrangements regarding the working age and work experience of female workers are necessary to facilitate the availability of qualified female workforce. Thus, the Indonesian government needs to consider minimum wages, education, work age, and work experience as policy instruments to increase female labor force participation rate.

As an archipelago country, the Indonesian central government inherently has spans of control problems with its local governments. Furthermore, Indonesia also implements the decentralization policy that delays the adoption of macro policies (e.g., labor policy). Consequently, the central government needs more adjustment time to ensure the synergy and harmonization between policies when implementing its policies to local governments. Thus, future studies need to consider the dynamic panel data to gain a better understanding of the short-run determinants of female labor force participation rate in each Indonesian province.

\section{REFERENCES}

Alamro, H. \& Al-dala'ien, Q. (2016). Validity of Okun's Law: Empirical Evidence from Jordan. Dirasat, Administrative Sciences, 43(1), 315-324. Retrieved from http://journals.ju.edu.jo/DirasatAdm/article/view/6788

Central Bureau of Statistics. (2019). Keadaan Ketenagakerjaan Indonesia Februari 2019. Retrieved from https://nakertrans.jogjaprov.go.id/resources/download/194/23.\% 20KEADAAN\%20TENAGA\%20KERJA\%20FEBRUARI\%202019\%20SUMBER\%20 BRS\%20BPS\%20DIY.pdf

Bozkaya, G. (2013). Kadinlarinİşgücüne KatiliminiBelirleyen Faktörler:Türkiye ÜzerineBirAnaliz. Sosyal Bilimler Dergisi, 3(5), 69-89. Retrieved from http://journal.dogus.edu.tr/index.php/duj/article/view/281/pdf

Çatalbaş, G. K. (2015). Kadınların İşgücüne Katılımını Belirleyen Faktörlerin Belirlenmesi: Panel Veri Yaklaşımı. Kafkas Üniversitesi İktisadi ve İdari Bilimler Fakültesi Dergisi, 6(10), 249-280. Retrieved from https://www.ceeol.com/search/article-detail?id=496962

Chen, J., Shao, X., Murtaza, G. \& Zhao, Z. (2014). Factors that influence female labor force supply in China. Economic Modelling, 37, 485-491. https://doi.org/10.1016/ j.econmod.2013.11.043

Chodijah, R. (2008). Nilai-Nilai Ekonomi Rumah Tangga dalam Mempengaruhi Keputusan Wanita di Perkotaan untuk Masuk Pasar Kerja di Sumatera Selatan. Jurnal Ekonomi Pembangunan, 6(2), 85-95. Retrieved from https://ejournal.unsri.ac.id/ index.php/jep/article/view/4854/2601

Dimian, G. C., Aceleanu, M. I., Ileanu, B. V. \& Șerban, A. C. (2018). Unemployment and Sectoral Competitiveness in Southern European Union Countries. Facts and Policy Implications. Journal of Business Economics and Management, 19(3), 474-499. https://doi.org/10.3846/jbem.2018.6581 
Ehrenberg, R. G. \& Smith, R. S. (2012). Modern Labor Economics: Theory and Public Policy (11th ed.). Boston: Pearson Education, Inc.

Er, Ş. (2013). Türkiye'de Kadinlarin Işgücüne Katilim Oranini Etkileyen Faktörlerin Bölgesel Analizi. Öneri Dergisi, 10(40), 35-44.

Granger, C. W. J. \& Newbold, P. (1974). Spurious Regression in Econometrics. Journal of Econometrics, 2(2), 111-120. https://doi.org/10.1016/0304-4076(74)90034-7

Gujarati, D. N. \& Porter, D. C. (2012). Dasar-Dasar Ekonometrika (5th ed.). Jakarta: Salemba Empat.

Handayani, H. R. \& Majid, F. (2012). Faktor-Faktor yang Mempengaruhi Keputusan Perempuan Berstatus Menikah untuk Bekerja (Studi Kasus Kota Semarang). Diponegoro Journal of Economics, 1(1), 1-9.

Hare, D. (2016). What accounts for the decline in labor force participation among married women in urban China, 1991-2011? China Economic Review, 38, 251-266. https://doi.org/10.1016/j.chieco.2016.01.004

Indonesia-Investments. (2019). Unemployment in Indonesia. Retrieved from https://www.indonesia-investments.com/finance/macroeconomic-indicators/ unemployment/item 255

Jaba, E., Sandu, C., Plopeanu, A., Robu, I. \& Istrate, M. (2017). The Statistical Analysis of Labor Market and Female Labor Force Characteristics in Central and Eastern European Countries. Studies and Scientific Researches. Economics Edition, (25), 19-33. https://doi.org/10.29358/sceco.v0i25.389

Johnson, W. R. (2014). House prices and female labor force participation. Journal of Urban Economics, 82, 1-11. https://doi.org/10.1016/j.jue.2014.05.001

Kizilgöl, Ö. A. (2012). Kadinlarin Işgücüne Katiliminin Belirleyicileri: Ekonometrik Bir Analiz. Doğuş Üniversitesi Dergisi, 13(1), 88-101. Retrieved from http://journal.dogus.edu.tr/index.php/duj/article/view/281/pdf

Lahoti, R. \& Swaminathan, H. (2013). Economic Growth and Female Labour Force Participation in India. In IIM Bangalore Research Paper (No. 414). https://doi.org/10.2139/ssrn.2284073

Lechman, E. \& Okonowicz, A. (2013). Are Women Important for Economic Development? An Evidence on Women's Participation in Labor Market and Their Contribution To Economic Growth. In GUT Faculty of Management and Economics Working Paper Series A (Economics, Management, Statistics) (No. 13). Retrieved from https://ideas.repec.org/p/gdk/wpaper/13.html

Lee, C.-W. \& Huruta, A. D. (2019). Okun's law in an emerging country: An empirical analysis in Indonesia. International Entrepreneurship Review, 5(4), 141-161. https://doi.org/10.15678/IER.2019.0504.09

Lee, N. \& Chung, J.-S. (2008). Interrelation between fertility and female labor force in Korea. Journal of Applied Business Research, 24(4), 139-151. https://doi.org/10.19030/ jabr.v24i4.1336

Mankiw, N. G. (2016). Macroeconomics (9th ed.). New York: Worth.

Mujahid, N. \& Zafar, N. U. (2012). Economic growth-female labour force participation nexus: An empirical evidence for Pakistan. Pakistan Development Review, 51(4), 
565-585. https://doi.org/10.30541/v51i4iipp.565-586

Mushtaq, A., Mohsin, A. \& Zaman, K. (2013). Effects of health on changing labor force participation in Pakistan. SpringerPlus, 2(1), 1-10. https://doi.org/10.1186/21931801-2-610

Niemi, B. T. \& Lloyd, C. B. (1981). Female Labor Supply in the Context of Inflation. American Economic Review, 71(2), 70-75. Retrieved from http://search.ebscohost. com/login.aspx?direct=true \&db=bth\&AN=4500223\&site=ehost-live \&scope $=$ site

Özer, M. \& Biçerli, K. (2003). Türkiye'de Kadın İşgücünün Panel Veri Analizi. Anadolu Üniversitesi Sosyal Bilimler Dergisi, 3(1), 55-86. Retrieved from http://www.acarindex.com/dosyalar/makale/acarindex-1423869751.pdf

PeiZhi, W. \& Ramzan, M. (2020). Do corporate governance structure and capital structure matter for the performance of the firms? An empirical testing with the contemplation of outliers. PLoS ONE, 15(2), 1-25. https://doi.org/10.1371/journal.pone.0229157

Riyadi, S. (2001). Analisis Faktor-Faktor yang Mempengaruhi Tingkat Partisipasi Angkatan Kerja Wanita Daerah Tingkat I Jawa Timur. Ekuitas, 5(1), 32-4.

Rosadi, D. (2012). Ekonometrika dan Analisis Runtun Waktu Terapan Dengan Eviews. Yogyakarta: ANDI.

Samuelson, P. A. \& Nordhaus, W. D. (2009). Economics (19th ed.). United States: McGrawHill Education.

Sarsi, W., Putro, T. S. \& Sari, L. (2014). Pengaruh Tingkat Upah dan Pertumbuhan Ekonomi terhadap Tingkat Partisipasi Angkatan Kerja di Provinsi Riau. Jurnal Online Mahasiswa Fakultas Ekonomi Universitas Riau, 1(2), 1-15. Retrieved from https://media.neliti.com/media/publications/33551-ID-pengaruh-tingkat-upah-danpertumbuhan-ekonomi-terhadap-tingkat-partisipasi-angka.pdf

Setyowati, E. (2009). Analisis Tingkat Partisipasi Wanita Dalam Angkatan Kerja di Jawa Tengah Periode Tahun 1982-2000. Jurnal Ekonomi Pembangunan: Kajian Masalah Ekonomi Dan Pembangunan, 10(2), 215-233. https://doi.org/10.23917/jep.v10i2.801

Tam, H. (2011). U-shaped female labor participation with economic development: Some panel data evidence. Economics Letters, 110(2), 140-142. https://doi.org/ 10.1016/j.econlet.2010.11.003

World Bank (2014). East Asia Pacific at Work: Employment, Enterprise \& Well-Being. Retrieved from The World Bank website: https://www.indonesiainvestments.com/news/news-columns/world-bank-report-east-asia-pacific-at-workemployment-enterprise-and-well-being/item1976

Todaro, M. P. \& Smith, S. C. (2015). Economic Development (12th ed.). New York: Pearson.

Tsani, S., Paroussos, L., Fragiadakis, C., Charalambidis, I. \& Capros, P. (2013). Female labour force participation and economic growth in the South Mediterranean countries. Economics Letters, 120(2), 323-328. https://doi.org/10.1016/j.econlet.2013.04.043

Varol, F. (2017). The Determinants of Labor Force Participation of Women In Turkey: A Binary Logit Analysis. Journal of History Culture and Art Research, 6(2), 92-108. https://doi.org/10.7596/taksad.v6i2.564

Winarno, W. W. (2015). Analisis Ekonometrika dan Statistika dengan Eviews (4th ed.). Yogyakarta: UPP STIM YKPN. 